Article

\title{
Organic-free synthesis of MOR nanoassemblies with excellent DME carbonylation performance
}

\author{
Kaipeng Cao a,b, Dong Fan a, Shu Zeng a,b, Benhan Fan a,b, Nan Chen a,b, Mingbin Gao a,b, Dali Zhu a,b, \\ Linying Wang a, Peng Tian a,* , Zhongmin Liu a,b,\# \\ a National Engineering Laboratory for Methanol to Olefins, Dalian National Laboratory for Clean Energy, Dalian Institute of Chemical Physics, Chinese \\ Academy of Sciences, Dalian 116023, Liaoning, China \\ b University of Chinese Academy of Sciences, Beijing 100049, China
}

\section{A R T I C L E I N F O}

\section{Article history:}

Received 19 November 2021

Accepted 2 February 2021

Available online 5 May 2021

\section{Keywords:}

MOR zeolite

Organic-free synthesis

DME carbonylation

Acidity

Diffusion

\begin{abstract}
A B S T R A C T
Seed-assisted low alkalinity gel system was developed to explore the organic-free synthesis of MOR zeolite. MOR nanoassemblies with $\mathrm{Si} / \mathrm{Al}$ ratio (SAR) up to 9.4 and high solid yield (84-94\%) were successfully obtained under controlled low alkalinity conditions. Characterization results demonstrate that the acid strength increases in parallel with the SAR, while the total acid amount and the proton distribution in the main channels and the side pockets are similar for the samples. The proton distribution in the $\mathrm{H}-\mathrm{MOR}$ is not straightforwardly related to the $\mathrm{Na}^{+}$distribution in the as-synthesized MOR, implying the transfer of the protons among the oxygen sites of framework $\mathrm{T}$ atom. Relative to low-silica samples I-5.3 and I-7.4, sample I-9.4 displays the best mass transfer performance and accessibility of the acid sites by pyridine due to its relatively low $\mathrm{Al}$ density and mild dealumination degree. Correspondingly, sample I-9.4 (pyridine-modified catalyst) shows the best activity with $c a$. 100\% selectivity of methyl acetate (MAc) in the DME carbonylation reaction. The high steady MAc yield $(6.8 \mathrm{mmol} / \mathrm{g} / \mathrm{h})$ over sample I-9.4 suggests the promising application of MOR nanoassemblies synthesized by this economical organic-free strategy.
\end{abstract}

(C) 2021, Dalian Institute of Chemical Physics, Chinese Academy of Sciences. Published by Elsevier B.V. All rights reserved.

\section{Introduction}

Zeolite-catalyzed DME carbonylation reaction has been arousing great attention in recent years, as it provides a non-noble metal catalysis route to realize the efficient and selective conversion of $\mathrm{C} 1$ resources to high-value chemical [1-5]. The carbonylation product MAc can be further converted by hydrogenation to yield ethanol, which is an important fuel additive and chemical feedstock traditionally produced by fermentation of biomass [6]. Therefore, DME carbonylation offers an alternative route to produce ethanol from coal and natural gas. A coal-to-ethanol plant (100,000 tons/year ethanol) including zeolite-catalyzed DME carbonylation process has indeed been put into production in Shaanxi in 2017 [7].

Among the zeolitic catalysts investigated for DME carbonylation, mordenite (MOR) shows a relatively high activity and MAc selectivity [8]. The MOR framework is composed of 12-membered ring (12-MR) channels and 8-MR channels along the $\mathrm{c}$ direction, which are interconnected by 8 -MR side pockets along the $b$ direction $[9,10]$. Previous works have demonstrat-

\footnotetext{
* Corresponding author. E-mail: tianpeng@dicp.ac.cn

\# Corresponding author. E-mail: liuzm@dicp.ac.cn

This work was supported by the National Natural Science Foundation of China (21676262, 21991090, 21991091), Key Research Program of Frontier Sciences, Chinese Academy of Sciences (QYZDB-SSW-JSC040), and the funding from the French-Sino International Laboratory (LIA) "Zeolites".

DOI: 10.1016/S1872-2067(20)63777-9 | http://www.sciencedirect.com/journal/chinese-journal-of-catalysis | Chin. J. Catal., Vol. 42, No. 9, September 2021
} 
ed that the Brønsted acid sites (BAS) in the side pockets are the unique active centers for carbonylation reaction due to spatial confinement [11-13], while the acid sites located in the main channels mainly catalyze DME to hydrocarbons, causing fast coke deposition and thus rapid deactivation of MOR catalysts $[12,14]$.

In order to alleviate the deactivation of MOR catalysts in DME carbonylation, several post-synthesis treatment methods have been developed, including selective dealumination [5,15], metal modification $[2,16]$ and pyridine modification $[17,18]$ etc. Among these strategies, pyridine modification seems the most effective one showing better catalytic stability and activity. Recently, we studied the pyridine adsorption/desorption behaviors on H-MOR and found that pyridine can interact with the acid sites both in the main channels and the side pockets. However, the pyridine in the pockets shows a preferential desorption upon heating, yielding a catalyst with pyridine-modified 12-MR channels and improved carbonylation activity/stability [19].

Great efforts are also dedicated to the direct synthesis of MOR zeolites in an attempt to improve the carbonylation activity and stability, which includes the synthesis of mesoporous/nanosized MOR for enhancing the mass transfer [20-23], and the Al distribution control for increasing the acid sites in the pockets [24-29]. Generally, the use of particular organic structure-directing agents (OSDAs) or organic additives/solvents is necessary to achieve a satisfied control on the synthetic product, which, however, causes relatively high cost and environmental pollution [30]. It would be highly desirable to realize the organic-free synthesis of MOR zeolite with improved DME carbonylation performance.

The SAR of MOR zeolite synthesized by traditional organic-free method is normally in the range of 5-7, and the crystals sizes are large [31-33]. Seed-assisted synthesis strategy has been demonstrated to be an effective method to avoid the use of OSDAs and decrease the product crystal sizes [34-37]. However, even with the help of seeds [31] or seed solution [34], MOR zeolites from OSDA-free system tend to show a nanorod morphology with preferential growth along the 12-MR channels, which is helpless for the alleviation of diffusion limitation in carbonylation reaction. Moreover, few reports can be found on the SAR improvement of the MOR zeolites synthesized from inorganic system, and thus the effect of SAR variation of the corresponding MOR on the acidity, acid distribution and DME carbonylation performance remains unclear.

Herein, we report the seed-assisted organic-free synthesis of MOR zeolites with widened SAR range and short diffusion path by controlling the gel system in lower alkalinity. The samples with different SARs are well characterized, and their catalytic performance for DME carbonylation are explored and correlated with the acidity and diffusion properties. Interestingly, pyridine-modified MOR with SAR of 9.4 displays remarkable catalytic activity together with nearly 100\% MAc selectivity.

\section{Experimental}

\subsection{Synthesis and preparation}

The typical procedure for the organic-free synthesis of MOR zeolites was as follows. Sodium aluminate (47.6 wt $\% \mathrm{Al}_{2} \mathrm{O}_{3}$, 36.6 wt $\% \mathrm{Na}_{2} \mathrm{O}$, Tianjin Guangfu Chemical Co.) and sodium hydroxide were dissolved in water at first. Subsequently, silica sol (27.5 wt $\% \mathrm{SiO}_{2}, 0.32 \mathrm{wt} \% \mathrm{NaO}_{2}$, Qingdao Chengyu Chemical Co.) was added dropwise under intense stirring. After aging for $1 \mathrm{~h}$, commercial MOR (ZR CATALYST Co., Ltd., corresponding composition and textural properties shown in Table S1) as seed ( $4 \mathrm{wt} \%$ relative to $\mathrm{SiO}_{2}$ ) was introduced and the resultant gel was stirred for another $1 \mathrm{~h}$. Finally, the mixture was introduced into a $100 \mathrm{~mL}$ autoclave and crystallized at $170{ }^{\circ} \mathrm{C}$ under static conditions. After crystallization, the solids were recovered, washed and then dried at $100{ }^{\circ} \mathrm{C}$. To obtain acidic H-MOR, the as-synthesized Na-MOR sample was ion-exchanged with $\mathrm{NH}_{4} \mathrm{NO}_{3}$ solution $(1 \mathrm{~mol} / \mathrm{L})$ at $80^{\circ} \mathrm{C}$ for $1 \mathrm{~h}$. The procedure was repeated for 3 times. The obtained solid was then washed, dried and calcined at $550{ }^{\circ} \mathrm{C}$ for $4 \mathrm{~h}$.

The samples are named I- $x$, where $x$ indicates the bulk phase $\mathrm{Si} / \mathrm{Al}$ ratio detected by XRF. Moreover, three contrast samples are synthesized with the same recipe as I-9.4 but without seed addition, with higher and lower gel alkalinity, which are denoted I-9.4-N, I-9.4-H and I-9.4-L, respectively.

\subsection{Characterization}

X-ray diffraction (XRD) patterns were measured on a PANalytical X'Pert PRO X-ray diffractometer with $\mathrm{Cu} K_{\alpha}$ radiation $(\lambda=$ $0.154 \AA$ ) at $40 \mathrm{kV}$ and $40 \mathrm{~mA}$. Elemental compositions were performed on an X-ray fluorescence spectrometer (XRF, Philips Magix-601). Scanning electron microscope (SEM) images were obtained using a Hitachi SU8020 SEM equipment. Selected area electron diffraction (SAED) patterns and high resolution transmission electron microscopy (HRTEM) images were acquired on the JEOL JEM-2100 TEM. Nitrogen adsorption isotherms were measured using a Micromeritics ASAP 2020 analyzer. The micropore area $\left(S_{\text {micro }}\right)$ and micropore volume $\left(V_{\mathrm{mi}}\right.$ cro) were determined by t-plot method. The total surface areas $\left(S_{\mathrm{BET}}\right)$ are calculated using BET method, while the total pore volumes $\left(V_{\text {total }}\right)$ were obtained at $P / P_{0}=0.97 . \mathrm{NH}_{3}$-TPD analysis was measured on Micromeritics Autochem II 2920. $100 \mathrm{mg}$ H-type samples were pretreated at $450{ }^{\circ} \mathrm{C}$ for $1 \mathrm{~h}$ under a $\mathrm{He}$ gasflow, and saturated with $\mathrm{NH}_{3}$ afterwards. The desorption process then was operated from 100 to $700{ }^{\circ} \mathrm{C}$. The solid-state nuclear magnetic resonance (NMR) experiments were performed on a Bruker Avance III 600 spectrometer equipped with a $14.1 \mathrm{~T}$ wide-bore magnet using a $4 \mathrm{mmWVT}$ double resonances MAS probe. ${ }^{29} \mathrm{Si}$ MAS NMR spectra were recorded at 119.2 $\mathrm{MHz}$ with a spinning rate of $8 \mathrm{kHz}$ using high-power proton decoupling with a $\pi / 4$ pulse width of $2.5 \mu \mathrm{s}$ and a recycle delay of $10 \mathrm{~s} .{ }^{27} \mathrm{Al}$ MAS NMR investigations were carried out at $156.4 \mathrm{MHz}$ with a $12 \mathrm{kHz}$ spinning rate, one pulse sequence adopted, with a $\pi / 8$ pulse width of $0.75 \mu$ s and a recycle delay of $2 \mathrm{~s}$. The samples were dehydrated at $400{ }^{\circ} \mathrm{C}$ for $12 \mathrm{~h}$ to remove the physisorbed water before the measurement of ${ }^{23} \mathrm{Na}$ MAS NMR spectra. Experiments were then performed at 158.7 
$\mathrm{MHz}$, with a pulse length of $0.2 \mu \mathrm{s}(\sim \pi / 8)$, and a recycle delay of $0.5 \mathrm{~s}$. The chemical shifts of ${ }^{29} \mathrm{Si},{ }^{27} \mathrm{Al}$ and ${ }^{23} \mathrm{Na}$ and were referenced to Kaolinite, $\mathrm{Al}\left(\mathrm{NO}_{3}\right)_{3}$ solution $(1 \mathrm{~mol} / \mathrm{L})$ and $\mathrm{NaCl}$ solution (1 mol/L) solution, respectively.

The uptake rate and adsorption isotherm were determined using an Intelligent Gravimetric Analyzer (IGA). About $25 \mathrm{mg}$ pyridine-modified MOR catalyst (40-60 mesh) was added to the chamber and outgassed until reaching to a constant weight at $300{ }^{\circ} \mathrm{C}$. Then the flowrate of MAc vapor was introduced. The adsorption kinetics curve was recorded at a pressure of $1 \mathrm{mbar}$, $50{ }^{\circ} \mathrm{C}$. Quantification of the effective diffusivity was attained using Fick's second law, to describe the variation of the MAc concentration inside the pyridine-modified catalyst as a function of time [38-40].

$$
\frac{\partial C}{\partial t}=D_{e f f}\left(\frac{\partial^{2} C}{\partial x^{2}}\right)
$$

Where $C$ is the concentration of MAc inside the particle, $t$ the time, $x$ the distance and $D_{\text {eff }}$ the diffusivity. During the initial stage of adsorption, the solution of this equation could be well approximated by [38-40]:

$$
\frac{m_{t}}{m_{\infty}}=\frac{2}{\sqrt{\pi}} \sqrt{\frac{D_{e f f}}{L^{2}}} \sqrt{t}
$$

Where $m_{t} / m_{\infty}$ is the normalized MAc uptake, $L$ the characteristic diffusion length.

Fourier transform infrared spectra (FTIR) were collected using a Bruker Tensor 27 instrument equipped with a MCT detector. Self-supported wafers of samples $(20 \mathrm{mg})$ were placed into an in situ quartz cell equipped with $\mathrm{CaF}_{2}$ windows. The wafers were subsequently pretreated at $400{ }^{\circ} \mathrm{C}$ for $30 \mathrm{~min}$ in vacuum. After pretreatment, the spectra were recorded at room temperature (RT) in the range of $400-4000 \mathrm{~cm}^{-1}$ (resolution: $4 \mathrm{~cm}^{-1}$ ). Afterwards, $\mathrm{NH}_{3}$ was introduced at $150{ }^{\circ} \mathrm{C}$ until saturation, followed by evacuation for $30 \mathrm{~min}$ to eliminate physisorbed $\mathrm{NH}_{3}$ and the corresponding spectra were recorded after cooling to RT. When pyridine was taken as the probe molecules, similar pretreatment procedure was carried out. Afterwards, the wafers were put in contact with pyridine vapour at $150{ }^{\circ} \mathrm{C}$ until reaching to an equilibrium, and then the FTIR spectra were recorded at RT. Subsequently, the samples were heated to $300{ }^{\circ} \mathrm{C}$ for pyridine adsorption as well as desorption. The spectra were collected after the sample was cooled to RT.

\subsection{DME carbonylation reaction}

The reaction was carried out in a high-pressure fixed-bed reactor. Typically, H-MOR sample (0.5 g, 40-60 mesh) was packed into the reactor, heated to $400{ }^{\circ} \mathrm{C}$ under $\mathrm{N}_{2}$ flow and purged at $400{ }^{\circ} \mathrm{C}$ for $2 \mathrm{~h}$. After the reactor was cooled to $300^{\circ} \mathrm{C}$, pyridine- $\mathrm{N}_{2}$ mixture $(30 \mathrm{~mL} / \mathrm{min})$ was introduced and purged for $30 \mathrm{~min}$, which was followed by flushing with $\mathrm{N}_{2}$ (30 $\mathrm{mL} / \mathrm{min}$ ) for $1 \mathrm{~h}$. Afterwards, the reactor was cooled further and maintained at $200 \quad{ }^{\circ} \mathrm{C}$. A gas mixture (DME/CO $/ \mathrm{N}_{2}=5 / 35 / 60$, Dalian Guang Ming Special Gas Co., Ltd.) was then introduced with a GHSV of $3600 \mathrm{~mL} / \mathrm{g} / \mathrm{h}$ and pressurized to 2.0 MPa. The product analyses were determined on an online gas chromatograph (Agilent 7890B) equipped with FID detector and Pora PLOT Q capillary column.

\section{Results and discussion}

\subsection{Seed-assisted organic-free synthesis of MOR nanoassemblies}

The organic-free syntheses of MOR zeolites were carried out under a judiciously designed low-alkalinity system with the assistance of seed crystals. The detailed synthetic conditions and corresponding results are listed in Table 1. It can be found that the SAR of the product rises following the increase of the initial gel SAR. The highest value can achieve as high as 9.4 together with a high solid yield of $94 \%$, which is uncommon for the synthesis of MOR zeolite without the help of OSDA $[33,41-43]$. The reason may be attributed to the low gel alkalinity $\left(\mathrm{OH}^{-} / \mathrm{Si}=0.16\right)$, in contrast to the usually higher alkalinity of the previous inorganic system [44]. This speculation is supported by the distinct results of the synthesis trials for I-9.4 and I-9.4-H. The higher alkalinity for the synthesis of I-9.4-H causes a reduced product SAR (8.1) and decreased yield, owing to the increased dissolution of silica species in the liquid phase. However, it is noted that although low alkalinity favors the improvement of SAR, the crystallization would be difficult to proceed if the gel alkalinity $\left(\mathrm{OH}^{-} / \mathrm{Si}\right.$ ) is lower than 0.13 (sample I-9.4-L). The crucial effect of seed addition for the synthesis can

Table 1

\begin{tabular}{|c|c|c|c|c|c|c|c|c|}
\hline \multirow{2}{*}{ Sample } & \multicolumn{4}{|c|}{ Gel molar composition ${ }^{a}$} & \multirow{2}{*}{ Time (h) } & \multicolumn{2}{|c|}{ Product } & \multirow{2}{*}{ Solid yield ${ }^{\mathrm{c}}(\%)$} \\
\hline & $\mathrm{SiO}_{2}$ & $\mathrm{Al}_{2} \mathrm{O}_{3}$ & $\mathrm{Na}_{2} \mathrm{O}$ & $\mathrm{H}_{2} \mathrm{O}$ & & Phase & SAR b & \\
\hline $\mathrm{I}-5.3$ & 1.0 & 0.08 & 0.13 & 15 & 30 & MOR & $5.3(5.2)$ & 88 \\
\hline $\mathrm{I}-7.0$ & 1.0 & 0.06 & 0.13 & 15 & 30 & MOR & $7.0(7.3)$ & 84 \\
\hline $\mathrm{I}-9.4$ & 1.0 & 0.05 & 0.08 & 15 & 30 & MOR & $9.4(9.8)$ & 94 \\
\hline $\mathrm{I}-11.9$ & 1.0 & 0.04 & 0.08 & 15 & 30 & $\mathrm{MOR}+\mathrm{U}$ e & 11.9 & - \\
\hline $\mathrm{I}-9.4-\mathrm{N}$ d & 1.0 & 0.05 & 0.08 & 15 & 110 & MOR+MFI & - & - \\
\hline $\mathrm{I}-9.4-\mathrm{H}$ & 1.0 & 0.05 & 0.13 & 15 & 13 & MOR & 8.1 & 81 \\
\hline I-9.4-L & 1.0 & 0.05 & 0.067 & 15 & 110 & MOR+Amorphous & - & - \\
\hline
\end{tabular}

Synthesis conditions, product SAR and solid yields of MOR zeolites.

a Seed addition: $4 \mathrm{wt} \%$ relative to $\mathrm{SiO}_{2}$ resource, crystallization temperature: $170{ }^{\circ} \mathrm{C}$.

b The SAR (Si/Al ratio) was derived from XRF and the value in the bracket was calculated from ${ }^{29}$ Si MAS NMR.

c The yield was calculated based on the mass of silica and alumina.

d I-9.4-N: no seed addition for the synthesis.

e U: unknown layered phases. 

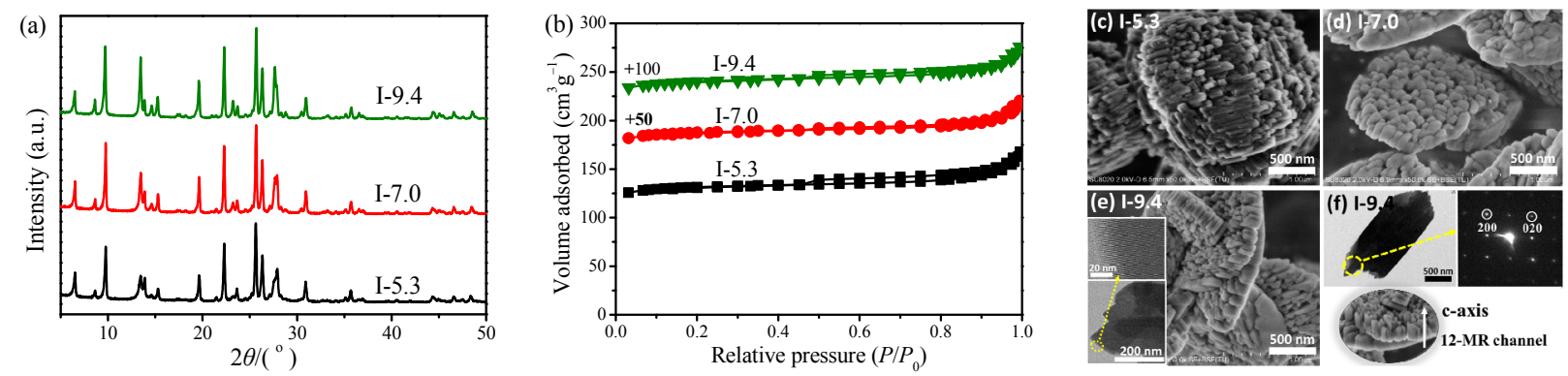

Fig. 1. (a) XRD patterns of the as-synthesized MOR samples; (b) $\mathrm{N}_{2}$ adsorption-desorption isotherms of the H-MOR samples (the isotherms of I-7.0 and I-9.4 are offset by 50 and $100 \mathrm{~cm}^{3} / \mathrm{g}$, respectively); (c-e) SEM images of the as-synthesized samples. The insets in (e) show the HRTEM image of sample I-9.4. (f) TEM image of sample I-9.4, corresponding SAED pattern viewed along the [001] direction and a schematic to illustrate the 12-MR channel system.

be discerned from the results of sample I-9.4-N. Only amorphous product is obtained after crystallization for $30 \mathrm{~h}$. Further prolonging the time to $110 \mathrm{~h}$ could lead to well-crystallized product, which, however, is a mixture of MOR and MFI.

Samples I-5.3, I-7.0 and I-9.4 with incremental SAR are selected for detailed characterizations and carbonylation performance investigation. The results of other samples are displayed in the supporting information (Figs. S1-S5). Figs. 1(a) and S1 show the XRD patterns of the as-synthesized samples. The diffraction peaks could be well indexed to MOR zeolite and no impurity diffraction is observed. In addition, no resonance due to hexacoordinated $\mathrm{Al}$ species could be observed in the ${ }^{27} \mathrm{Al}$ MAS NMR spectra of the samples (Fig. 2(a)), evidencing the sole presence of framework $\mathrm{Al}$ species. Fig. 2(b) shows the ${ }^{29} \mathrm{Si} \mathrm{NMR}$ spectra of the samples. The resonances centered around -99 , -105 and $-112 \mathrm{ppm}$ are ascribed to $\mathrm{Si}(2 \mathrm{Al}), \mathrm{Si}(1 \mathrm{Al})$ and $\mathrm{Si}(0 \mathrm{Al})$ species, respectively [45]. With the increase of SAR, the relative proportions of the $\mathrm{Si}(1 \mathrm{Al})$ and $\mathrm{Si}(2 \mathrm{Al})$ decrease, corresponding to the ameliorated dispersion of the $\mathrm{Al}$ sites in the samples. Based on the deconvolution analysis of the ${ }^{29} \mathrm{Si}$ NMR spectra, the framework SAR are calculated and listed in Table 1. These values are quite similar to the bulk SAR derived from XRF.

The SEM images (Figs. 1(c)-(e)) reveal that sample I-5.3 is a cluster of nanorods with a diameter of $c a .50 \mathrm{~nm}$ and a length of 200-300 nm. Samples I-7.0 and I-9.4 are rough-surfaced plate-like crystals assembled by $50-200 \mathrm{~nm}$ irregular nanograins. The insets in Fig. 1(e) show the HRTEM image of sample I-9.4, which presents legible crystal lattice and evidences the good crystallinity of the sample. The SAED pattern in Fig. 1(f) reveals that the nanocrystal assemblies are indeed single crystal, and the shortest dimension of the assemblies runs along the [001] direction. Given that the $c$-axis is the direction of 12-MR main channels of MOR zeolite, this morphology is expected to be favorable for carbonylation reaction owing to the short diffusion path. The $\mathrm{N}_{2}$ physisorption isotherms and textural properties of the sample are displayed in Fig. 1(b) and Table 2, respectively. All three isotherms could be mainly regarded as type I isotherm with negligible hysteresis loops likely due to the stacking voids between the primary nano-particles. The $t$-plot micropore surface areas range from 374 to $392 \mathrm{~m}^{2} / \mathrm{g}$, and the micropore volume are calculated to be around $0.18-0.19 \mathrm{~cm}^{3} / \mathrm{g}$, verifying the good crystallinity of the samples.

For MOR synthesis, the presence of $\mathrm{Na}^{+}$is generally indis-

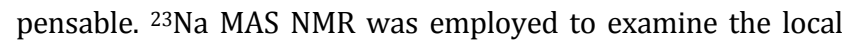
environments of $\mathrm{Na}^{+}$in the samples and the corresponding spectra are shown in Fig. 2(c). According to the previous literature [46], the ${ }^{23} \mathrm{Na}$ spectra of the dehydrated MOR samples can be deconvoluted into two bands, corresponding to the $\mathrm{Na}^{+}$ located in the 12-MR channels and the side pockets, respectively. From Fig. 2(c), it could be clearly inferred that a larger proportion of $\mathrm{Na}^{+}$is located in the side pockets and this proportion rises in parallel with the increase of the SAR, illustrating that the pockets are the preferential loci for the siting of $\mathrm{Na}^{+}$.

\subsection{Acid properties}

(a)

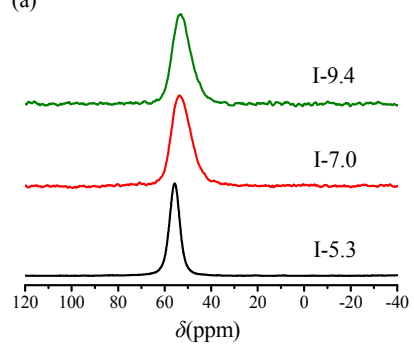

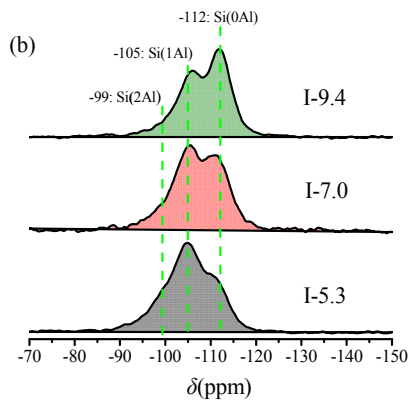

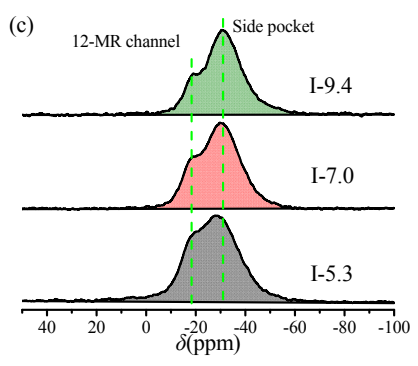

(c)

Fig. 2. (a) ${ }^{27} \mathrm{Al}$, (b) ${ }^{29} \mathrm{Si}$ and (c) ${ }^{23} \mathrm{Na}$ MAS NMR spectra of the as-synthesized samples. The samples were dehydrated at $400{ }^{\circ} \mathrm{C}$ for $12 \mathrm{~h}$ in vacuum before ${ }^{23} \mathrm{Na}$ MAS NMR measurement. 
Table 2

Textural properties of the samples.

\begin{tabular}{lccccccc}
\hline \multirow{2}{*}{ Sample } & \multicolumn{3}{c}{ Surface area $^{\mathrm{a}}\left(\mathrm{m}^{2} / \mathrm{g}\right)$} & & \multicolumn{3}{c}{ Pore volume ${ }^{\mathrm{b}}\left(\mathrm{cm}^{3} / \mathrm{g}\right)$} \\
\cline { 2 - 3 } \cline { 6 - 8 } & $S_{\text {BET }}$ & $S_{\text {micro }}$ & $S_{\text {ext }}$ & & $V_{\text {total }}$ & $V_{\text {micro }}$ & $V_{\text {meso }}$ \\
\hline $\mathrm{I}-5.3$ & 418 & 374 & 44 & & 0.24 & 0.18 & 0.06 \\
$\mathrm{I}-7.0$ & 438 & 392 & 47 & & 0.24 & 0.19 & 0.05 \\
$\mathrm{I}-9.4$ & 428 & 375 & 53 & & 0.24 & 0.18 & 0.06 \\
\hline
\end{tabular}

${ }^{\text {a }} S_{\text {ext }}=S_{\text {BET }}-S_{\text {micro; }}{ }^{\text {b }} V_{\text {meso }}=V_{\text {total }}-V_{\text {micro. }}$.

Since DME carbonylation is an acid-catalyzed reaction, the quantities and strength of the acid sites could exert significant influence on the catalytic performances of the catalysts. A comprehensive study on the acid properties of the MOR samples, including the number, strength, distribution and accessibility of the acid sites, was carried out. The $\mathrm{NH}_{3}$-TPD results of the samples are displayed in Fig. 3(a). The coexistence of two distinct peaks could be observed. The desorption peaks at low temperature $\left(195^{\circ} \mathrm{C}\right)$ correspond to physically adsorbed $\mathrm{NH}_{3}$ or weakly bonded $\mathrm{NH}_{3}$ from the weak acid sites, while the high-temperature peaks $\left(500-530{ }^{\circ} \mathrm{C}\right)$ are due to $\mathrm{NH}_{3}$ desorption from the acid sites of moderate/strong strength [47-52]. With the increase of SAR, the high-temperature peaks shift towards higher temperature, indicating the increased acid strength, possibly due to the decreased number of next-nearest Al neighbors in the framework [53,54]. In addition, signals due to de-hydroxyl could be observed at high temperature of around $600-700{ }^{\circ} \mathrm{C}$. These de-hydroxyl signals become more prominent following the decrease of SAR, which suggests the inferior thermal stability of the low silica samples. The deconvoluted $\mathrm{NH}_{3}$-TPD results are presented in Table 3 . In spite of their distinct $\mathrm{Al}$ contents, the samples show little variation in the total amounts of their moderate/strong acid sites, possibly due to more pronounced dealumination and consequently reduced framework Al content of the low silica samples

(a)

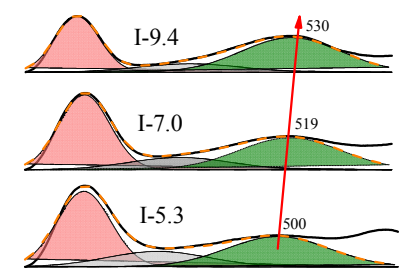

Temperature $\left({ }^{\circ} \mathrm{C}\right)$

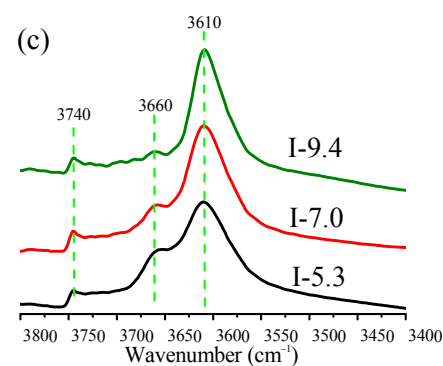

$\mathrm{NH}_{3}$-adsoprtion FTIR was further performed to distinguish the BAS and Lewis acid sites (LAS). As seen in Fig. 3(b), the bands at 1430 and $1620 \mathrm{~cm}^{-1}$ are attributed to $\mathrm{NH}_{3}$ interacted with BAS and LAS, respectively [55]. The results in Table 3 reveal obviously low BAS/LAS ratios on samples I-5.3 and I-7.0, verifying the severe dealumination on them.

The FTIR spectra in the $v(\mathrm{OH})$ vibration region are shown in Fig. 3(c), the band at around $3740 \mathrm{~cm}^{-1}$ is owing to the isolated silanol on the external surface [56], and the band at $3660 \mathrm{~cm}^{-1}$ arises from aluminol of extra-framework $\mathrm{Al}$ species $[57,58]$. The aluminol band is apparently more pronounced for I-5.3 and I-7.0, confirming again the serious dealumination on low silica samples. The most prominent FTIR band at $3610 \mathrm{~cm}^{-1}$ is ascribed to the bridging hydroxyls, which is actually a composite of two overlaid bands $[59,60]$. The high-frequency (HF) and low-frequency (LF) bands at 3612 and $3590 \mathrm{~cm}^{-1}$ are ascribed to the acidic hydroxyls in the 12-MR channels and the side pockets, respectively. A deconvolution analysis of the acidic hydroxyls was performed to determine the acid site distribution (Fig. 3(d)). To avoid the interference of overlapped aluminols, the bridging hydroxyls region in the difference spectra before and after $\mathrm{NH}_{3}$ adsorption was used for the deconvolution, as described in our previous study [19]. Interestingly, the acid distribution does not alter significantly relative to different SARs. This phenomenon, however, is in contradiction with the progressive variation of $\mathrm{Na}^{+}$distribution following the increased SAR (Fig. 2(c)). Given the fact that all the four non-equivalent crystallographic T sites of the MOR framework actually have covalently linked oxygen sites residing in the 8-MR side pockets, it is speculated that the $\mathrm{Na}^{+}$in the pockets might also partially balance the negative framework oxygen associated with the $\mathrm{Al}$ atoms outside the pockets $[61,62]$. Upon the replacement of the protons for $\mathrm{Na}^{+}$ions, a transfer of the protons from the oxygen sites inside the pockets to those be-

(b)

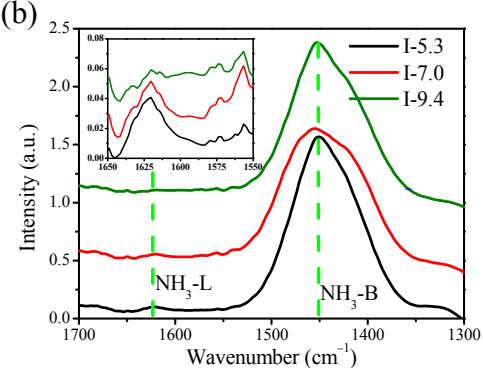

(d)

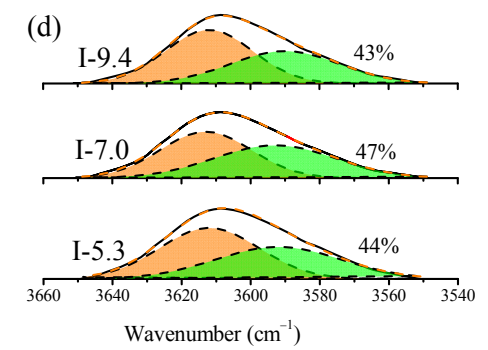

Fig. 3. Acidity of the H-MOR samples. (a) $\mathrm{NH}_{3}$-TPD profiles; (b) $\mathrm{NH}_{3}$-adsorption FTIR spectra; (c) FTIR spectra of H-MOR; (d) Deconvoluted bands corresponding to the acid hydroxyls in the 12-MR channels (HF) and the side pockets (LF). The numbers in (d) refer to the percentage of Brønsted acids in the side pockets. 
Table 3

Acid amounts of the H-MOR samples based on $\mathrm{NH}_{3}$-TPD and $\mathrm{NH}_{3}$-FTIR.

\begin{tabular}{|c|c|c|c|c|c|c|c|c|}
\hline \multirow{2}{*}{ Sample } & \multicolumn{4}{|c|}{$\mathrm{NH}_{3}-\mathrm{TPD}(\mathrm{mmol} / \mathrm{g})$} & \multicolumn{4}{|c|}{$\mathrm{NH}_{3}$-FTIR b $(\mathrm{mmol} / \mathrm{g})$} \\
\hline & Weak & Moderate & Strong & $\mathrm{M}+\mathrm{S}^{\mathrm{a}}$ & BAS & LAS & $\mathrm{B}+\mathrm{L}^{\mathrm{c}}$ & BAS/LAS \\
\hline $\mathrm{I}-5.3$ & 1.03 & 0.4 & 0.79 & 1.19 & 1.01 & 0.17 & 1.18 & 5.82 \\
\hline I-7.0 & 0.97 & 0.32 & 0.82 & 1.14 & 0.83 & 0.15 & 0.98 & 5.53 \\
\hline $\mathrm{I}-9.4$ & 0.77 & 0.26 & 0.89 & 1.15 & 0.91 & 0.08 & 0.99 & 10.87 \\
\hline
\end{tabular}

a $\mathrm{M}+\mathrm{S}=$ Moderate + Strong.

${ }^{\mathrm{b}}$ The extinction coefficient for the bands at $1430 \mathrm{~cm}^{-1}$ (BAS) and $1620 \mathrm{~cm}^{-1}$ (LAS) are 0.147 and $0.022 \mathrm{~cm}^{2} / \mu \mathrm{mol}$, respectively [55].

${ }^{c} \mathrm{~B}+\mathrm{L}=\mathrm{BAS}+\mathrm{LAS}$.

longing to the main channels occurs. This finding implies that the $\mathrm{Na}^{+}$siting in the as-synthesized MOR could not be straightforwardly interpreted into the proton distribution in the acidic H-MOR.

\subsection{Pyridine adsorption and accessibility of the acid sites}

Pyridine-modified MOR is effective catalyst for carbonylation reaction with good stability and high MAc selectivity due to the poisoning of the acids in the 12-MR channels. Our recent work revealed that pyridine could interact with acidic hydroxyls in the side pockets likely due to the defect sites in the framework, but this part of pyridine desorbs preferentially upon heating [19]. Herein, pyridine adsorption/desorption on the organic-free synthesized samples were investigated to study the pyridine modification process and the accessibility of the acid sites. Fig. 4(a) shows the FTIR spectra in the hydroxyl stretching region of the samples before and after pyridine adsorption at $150{ }^{\circ} \mathrm{C}$. For samples I-5.3 and I-7.0, residual acidic hydroxyls in both the 12-MR channels and side pockets can be observed after pyridine adsorption, indicating the poor accessibility of the acid sites. The reason for this might be twofold: (1) the severe dealumination and the inevitable aggravated creation of extra-framework Al species (EFAL) in the channels cause undesirable pore blockage for pyridine diffusion; (2) the higher local Al density of the two samples lead to higher local pyridine density upon pyridine adsorption, which may also block the diffusion path for pyridine to reach all the BAS. For sample I-9.4, all the BAS were covered after pyridine adsorption, implying their better accessibility, owing to the mild dealumination and better $\mathrm{Al}$ dispersion as corroborated by the ${ }^{29} \mathrm{Si}$ MAS NMR results. These results demonstrate that MOR samples with higher SAR has better accessibility of acid sites by pyridine.

After pyridine adsorption and desorption at $300{ }^{\circ} \mathrm{C}$ (the same temperature for the preparation of pyridine-modified H-MOR catalyst), the band due to the recovered acidic hydroxyls for sample I-9.4 is located at $3591 \mathrm{~cm}^{-1}$, which evidences that the exposed BAS are mainly from the side pockets. This may be owing to the lower adsorption stability of pyridine in the sterically confined pockets. However, for samples I-5.3 and I-7.0, the bands due to the exposed acidic hydroxyls are located at around 3605 and $3599 \mathrm{~cm}^{-1}$, respectively. It suggests the pyridine desorbs from both the 12-MR channels and the pockets, likely caused by their high/inhomogeneous local acid densities.

\subsection{Diffusion properties}

The mass transfer properties of the pyridine-modified H-MOR catalysts were evaluated by IGA. MAc was used as probe molecule since it is the preferential product in the carbonylation reaction. As shown in the uptake curves of Fig. 5(a), the MAc uptake in high silica sample I-9.4 is obviously accumulated much faster than I-5.3 and I-7.0. Quantification of diffusion properties for the three samples were attained using Fick's second law (Eq. (1)). The solution (Eq. (2)) can be fitted by plotting $m_{t} / m_{\infty}$ vs. $\sqrt{t}$, giving a good linearity as demonstrated in Fig. 5(b), and the corresponding values of $D_{\text {eff }} / L^{2}$ could be calculated from the slopes [39]. Fundamentally, $D_{\text {eff }}$ is determined by the inherent micropore structure, while $L$ is the characteristic diffusion length. Therefore, the value of $D_{\text {eff }} / L^{2}$ is a good indicator for the variation of the mass transfer rate [40]. From Fig. 5(b), the $D_{\text {eff }} / L^{2}$ value increases from $1.96 \times 10^{-5} \mathrm{~s}^{-1}$ (a)

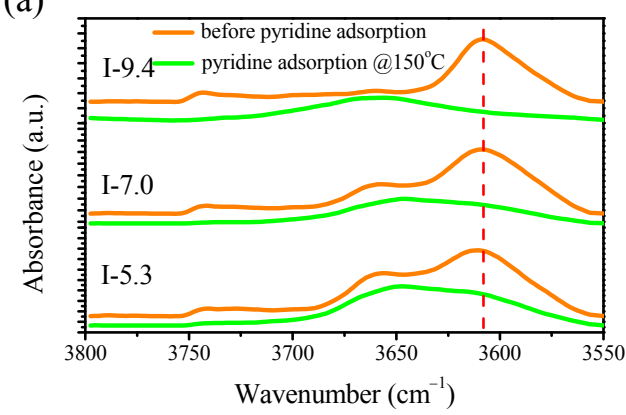

(b)

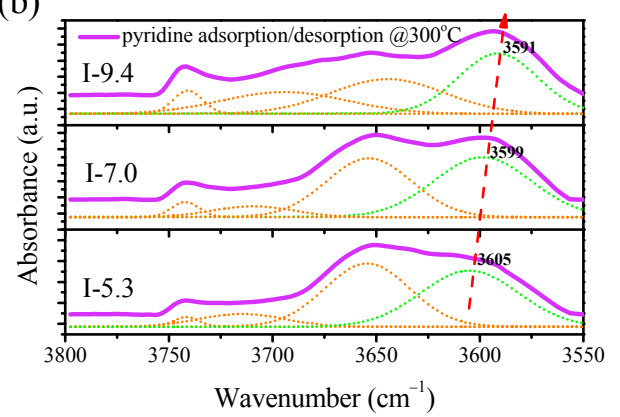

Fig. 4. $v(\mathrm{OH})$ vibration region of the H-MOR samples (a) before and after pyridine adsorption at $150{ }^{\circ} \mathrm{C}$, (b) after pyridine adsorption and desorption at $300^{\circ} \mathrm{C}$. 
(a)

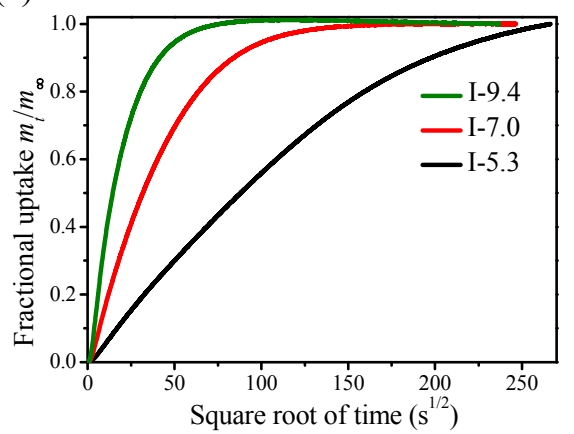

(b)

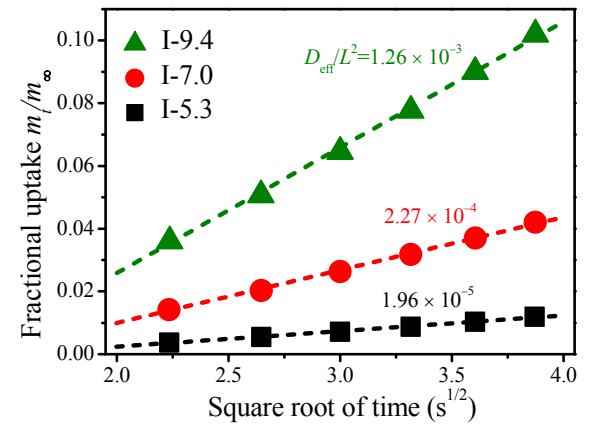

Fig. 5. (a) Uptake rate of MAc in pyridine-modified H-MOR measured by IGA $\left(50{ }^{\circ} \mathrm{C}, 1 \mathrm{mbar}\right)$. (b) Initial uptake rate. The scatters represent the experimental data while dash lines are fitting results by Eq. (2).

for I-5.3 to $2.27 \times 10^{-4}$ for I-7.0, and finally to $1.26 \times 10^{-3} \mathrm{~s}^{-1}$ for I-9.4, showing that I-9.4 has remarkable mass transfer properties. In consideration of that the similar grain sizes (diffusion path) of the samples can't explain this phenomenon, it can be reasonably inferred that the lower uptake rates on I-5.3 and I-7.0 are caused by the internal diffusion barriers. There could be two reasons for the barriers: 1) the existence of more EFAL species; 2) the higher local density of pyridine in the main channels of MOR with lower SAR, corresponding to the inhomogeneous distribution of acid sites.

\subsection{DME carbonylation}

Fig. 6 displays the DME carbonylation results on pyridine-modified H-MOR samples with different SARs. As can be seen from Fig. 6(a), the sample with higher SAR has better reaction activity. The conversion in the steady period on I-5.3 and I-7.0 is only $12 \%$ and $25 \%$ respectively, while that of I-9.4 is as high as $85 \%$. The superior activity of sample I-9.4 should be owing to its higher SAR and small grain size, which bring it higher acid strength, fewer extra-framework $\mathrm{Al}$ species, better accessibility of acid sites and mass transfer property. It is worth mentioning that the steady MAc yield $(6.8 \mathrm{mmol} / \mathrm{g} / \mathrm{h})$ on sample I-9.4 is among the highest value ever reported for the DME carbonylation using zeolitic catalysts.

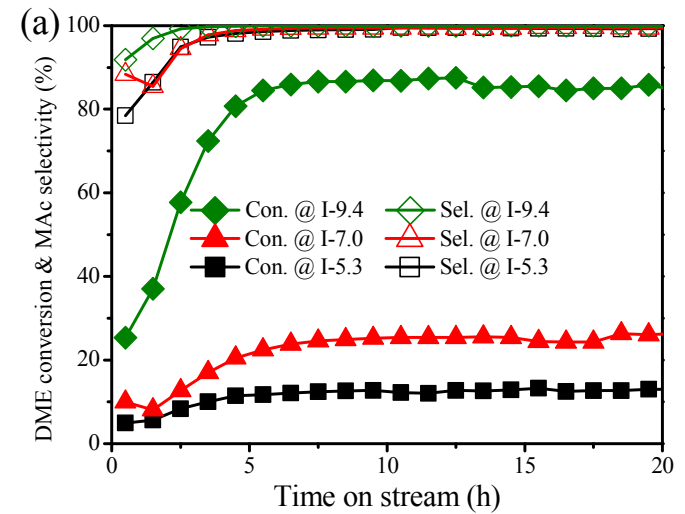

Regarding the product selectivity, although all three samples exhibit high MAc selectivity, some differences in the evolution of the by-products $\left(\mathrm{HC}_{x}\right)$ could be observed. From Fig. 6(b), low silica samples I-5.3 and I-7.0 clearly yield more by-products than sample I-9.4. This can be explained according to the accessibility of the acid sites and mass transfer properties of the samples, as discussed in the previous sections. That is, the acid sites in the main channels of samples I-5.3 and I-7.0 could not be completely covered by pyridine, which would inevitably cause the occurrence of side reactions. On the other hand, the inferior diffusion property on the low silica samples further increases the chance of side-reaction for the reactant and product diffusing through the main channels [63,64]. As the formation of by-products corresponds to the occurrence of DME to hydrocarbons and thus the deposition of coke, the extremely low selectivity of by-products on sample I-9.4 promises its superior long-term catalytic stability.

\section{Conclusions}

A series of nano-aggregated MOR zeolites was synthesized in a seed-assisted organic-free system. By controlling the gel system in low alkalinity, the SAR of the MOR products can be improved up to 9.4 together with high solid yield. It is found that with the increase of the SAR, the acid strength of the sam-

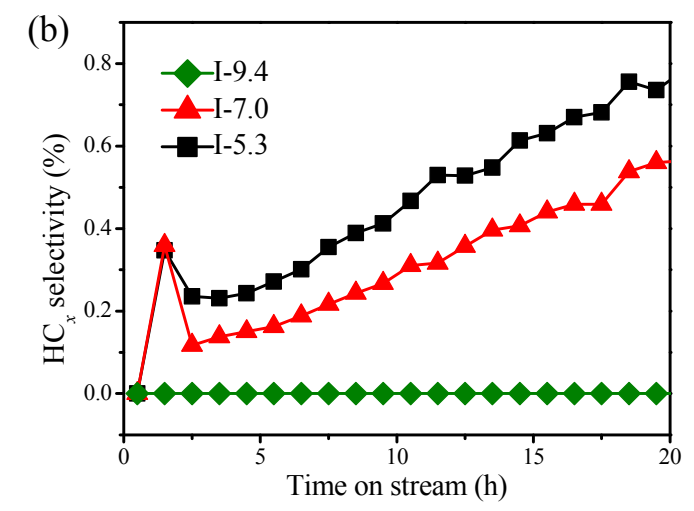

Fig. 6. (a) DME conversion during DME carbonylation over pyridine-modified H-MOR catalysts. (b) Hydrocarbon by-products (HC $\mathrm{C}_{x}$ ) selectivity. Reaction conditions: $200^{\circ} \mathrm{C}, 2 \mathrm{MPa}, \mathrm{GHSV}=3600 \mathrm{~mL} / \mathrm{g} / \mathrm{h}$. DME $/ \mathrm{CO} / \mathrm{N}_{2}=5 / 35 / 60$. 
ples rises and the dealumination degree decreases. But the total acid amount and the distribution of BAS in the main channels and the pockets remain similar for the samples. Due to the larger amount of EFAL, the low silica samples display low accessibility of the acid sites by pyridine and severe internal diffusion limitation, in spite of their small crystal size. High silica sample I-9.4 (pyridine-modified catalyst) exhibits superior catalytic activity in the DME carbonylation reaction, owing to its high acid strength and good mass transfer property. Moreover, as all the acid sites in the 12-MR channels of I-9.4 could be covered by pyridine, the occurrence of side reactions in the main channels is restrained, which leads to $c a .100 \%$ of MAc selectivity and promises the long-term stability of the catalyst.

\section{Author contributions}

All authors contributed to this work. All authors have given approval to the final version of the paper.

\section{Declaration of competing interest}

The authors declare no competing financial interest.

\section{Electronic supporting information}

Supporting information is available in the online version of this article.

\section{References}

[1] D. B. Rasmussen, J. M. Christensen, B. Temel, F. Studt, P. G. Moses, J. Rossmeisl, A. Riisager, A. D. Jensen, Angew. Chem. Int. Ed., 2015, 54, 7261-7264.

[2] A. A. C. Reule, N. Semagina, ACS Catal, 2016, 6, 4972-4975.

[3] P. Lu, Q. J. Chen, G. H. Yang, L. Tan, X. B. Feng, J. Yao, Y. Yoneyama, N. Tsubaki, ACS Catal., 2020, 10, 1366-1374.

[4] M. Lusardi, T. T. Chen, M. Kale, J. H. Kang, M. Neurock, M. E. Davis,
ACS Catal., 2020, 10, 842-851.

[5] W. Zhou, J. Kang, K. Cheng, S. He, J. Shi, C. Zhou, Q. Zhang, J. Chen, L. Peng, M. Chen, Y. Wang, Angew. Chem. Int. Ed., 2018, 57, 12012-12016.

[6] J. Goldemberg, Science, 2007, 315, 808-810.

[7] P. Grad, Debut of a coal-to-ethanol plant, 2017.

[8] P. Cheung, A. Bhan, G. J. Sunley, E. Iglesia, Angew. Chem. Int. Ed., 2006, 45, 1617-1620.

[9] M. Moliner, C. Martinez, A. Corma, Angew. Chem. Int. Ed., 2015, 54, 3560-3579.

[10] X. Li, R. Prins, J. A. van Bokhoven, J. Catal., 2009, 262, 257-265.

[11] P. Cheung, A. Bhan, G. J. Sunley, D. J. Law, E. Iglesia, J. Catal., 2007, 245, 110-123.

[12] M. Boronat, C. Martinez-Sanchez, D. Law, A. Corma, J. Am. Chem. Soc., 2008, 130, 16316-16323.

[13] B. Li, J. Xu, B. Han, X. Wang, G. Qi, Z. Zhang, C. Wang, F. Deng, J. Phys. Chem. C, 2013, 117, 5840-5847.

[14] D. B. Rasmussen, J. M. Christensen, B. Temel, F. Studt, P. G. Moses, J. Rossmeisl, A. Riisager, A. D. Jensen, Catal. Sci. Technol., 2017, 7, 1141-1152.

[15] H. F. Xue, X. M. Huang, E. S. Zhan, M. Ma, W. J. Shen, Catal. Commun., 2013, 37, 75-79.

[16] S. R. Wang, W. W. Guo, L. J. Zhu, H. X. Wang, K. Z. Qiu, K. F. Cen, J. Phys. Chem. C, 2015, 119, 524-533.

[17] J. Liu, H. Xue, X. Huang, P.-H. Wu, S.-J. Huang, S.-B. Liu, W. Shen, Chin. J. Catal., 2010, 31, 729-738.

[18] Y. Li, Q. Sun, S. Y. Huang, Z. Z. Cheng, K. Cai, J. Lv, X. B. Ma, Catal. Today, 2018, 311, 81-88.

[19] K. Cao, D. Fan, L. Li, B. Fan, L. Wang, D. Zhu, Q. Wang, P. Tian, Z. Liu, ACS Catal., 2020, 10, 3372-3380.

[20] L. Y. Bai, Z. P. Xiong, E. S. Zhan, S. Li, W. J. Shen, J. Mater. Sci., 2019, 54, 7589-7602.

[21] K. Lu, J. Huang, L. Ren, C. Li, Y. Guan, B. Hu, H. Xu, J. Jiang, Y. Ma, P. Wu, Angew. Chem. Int. Ed., 2020, 59, 6258-6262.

[22] M. Ma, X. Huang, E. Zhan, Y. Zhou, H. Xue, W. Shen, J. Mater. Chem. A, 2017, 5, 8887-8891.

[23] Y. Yuan, L. Wang, H. Liu, P. Tian, M. Yang, S. Xu, Z. Liu, Chin. J. Catal., 2015, 36, 1910-1919.

[24] B. Lu, T. Kanai, Y. Oumi, T. Sano, J. Porous Mater., 2007, 14, 89-96.

\section{Graphical Abstract}

Chin. J. Catal., 2021, 42: 1468-1477 doi: 10.1016/S1872-2067(20)63777-9

\section{Organic-free synthesis of MOR nanoassemblies with excellent DME carbonylation performance}

Kaipeng Cao, Dong Fan, Shu Zeng, Benhan Fan, Nan Chen, Mingbin Gao, Dali Zhu, Linying Wang, Peng Tian*, Zhongmin Liu*

Dalian Institute of Chemical Physics, Chinese Academy of Sciences; University of Chinese Academy of Sciences

MOR nanoassemblies with SAR up to 9.4 were synthesized efficiently via an organic-free route. A steady MAc yield of $6.8 \mathrm{mmol} / \mathrm{g} / \mathrm{h}$ with $\mathrm{ca}$. $100 \%$ selectivity was achieved on pyridine-modified H-MOR nanoassemblies with SAR of 9.4, owing to superior mass transfer performance and accessibility of the acid sites.

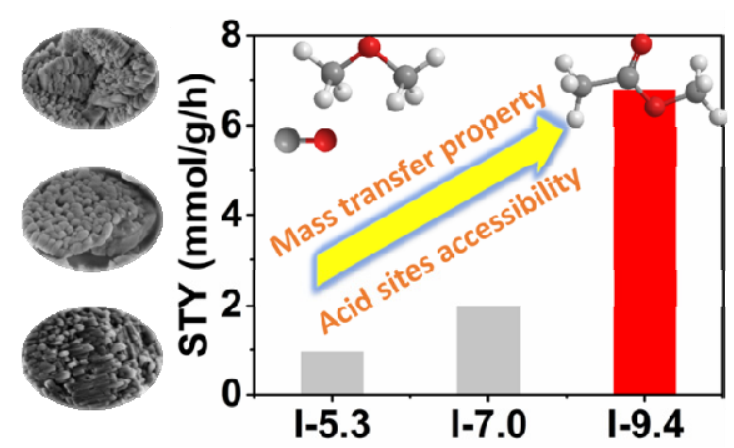


[25] M. Kato, K. Itabashi, A. Matsumoto, K. Tsutsumi, J. Phys. Chem. B, 2003, 107, 1788-1797.

[26] M. Kumar, Z. J. Berkson, R. J. Clark, Y. Shen, N. A. Prisco, Q. Zheng, Z. Zeng, H. Zheng, L. B. McCusker, J. C. Palmer, B. F. Chmelka, J. D. Rimer, J. Am. Chem. Soc., 2019, 141, 20155-20165.

[27] L. Y. Li, Q. Y. Wang, H. C. Liu, T. T. Sun, D. Fan, M. Yang, P. Tian, Z. M. Liu, ACS Appl. Mater. Interfaces, 2018, 10, 32239-32246.

[28] Y. Li, M. Yu, K. Cai, M. Wang, J. Lv, R. F. Howe, S. Huang, X. Ma, Phys. Chem. Chem. Phys., 2020, 22, 11374-11381.

[29] Y. Li, S. Y. Huang, Z. Z. Cheng, K. Cai, L. D. Li, E. Milan, J. Lv, Y. Wang, Q. Sun, X. B. Ma, Appl. Catal. B, 2019, 256, 12, 117777.

[30] J. Wang, S. W. Cheng, J. Guo, X. W. Xu, Y. C. Long, Microporous Mesoporous Mater., 2006, 96, 307-313.

[31] L. Zhang, S. Xie, W. Xin, X. Li, S. Liu, L. Xu, Mater. Res. Bull., 2011, 46, 894-900.

[32] X. Wang, R. Li, C. Yu, L. Zhang, C. Xu, H. Zhou, Microporous Mesoporous Mater., 2019, 274, 227-235.

[33] Y. Liu, N. Zhao, H. Xian, Q. Cheng, Y. Tan, N. Tsubaki, X. Li, ACS Appl. Mater. Interfaces, 2015, 7, 8398-8403.

[34] L. Ren, Q. Guo, H. Zhang, L. Zhu, C. Yang, L. Wang, X. Meng, Z. Feng, C. Li, F.-S. Xiao, J. Mater. Chem., 2012, 22, 6564-6567.

[35] J. W. Song, L. Dai, Y. Y. Ji, F. S. Xiao, Chem. Mater., 2006, 18, 2775-2777.

[36] L. Zhang, C. Yang, X. Meng, B. Xie, L. Wang, L. Ren, S. Ma, F.-S. Xiao, Chem. Mater., 2010, 22, 3099-3107.

[37] B. Xie, J. Song, L. Ren, Y. Ji, J. Li, F.-S. Xiao, Chem. Mater., 2008, 20, 4533-4535.

[38] M. Y. Kim, K. Lee, M. Choi, J. Catal., 2014, 319, 232-238.

[39] D. Jin, G. Ye, J. Zheng, W. Yang, K. Zhu, M.-O. Coppens, X. Zhou, ACS Catal., 2017, 7, 5887-5902.

[40] T. Yue, W. Liu, L. Li, X. Zhao, K. Zhu, X. Zhou, W. Yang, J. Catal., 2018, 364, 308-327.

[41] P. K. Bajpai, M. S. Rao, K. Gokhale, Ind. Eng. Chem. Product Res. Develop., 1978, 17, 223-227.

[42] B. O. Hincapie, L. J. Garces, Q. H. Zhang, A. Sacco, S. L. Suib, Microporous Mesoporous Mater., 2004, 67, 19-26.

[43] Y. Li, Z. Li, S. Huang, K. Cai, Z. Qu, J. Zhang, Y. Wang, X. Ma, ACS Appl. Mater. Interfaces, 2019, 11, 24000-24005.

[44] G. J. Kim, W. S. Ahn, Zeolites, 1991, 11, 745-750.
[45] S. Horike, R. Matasuda, S. Kitagawa, Stud. Surf. Sci. Catal., 2005, 156, 725-732.

[46] M. Hunger, P. Sarv, A. Samoson, Solid State Nucl. Magn. Reson., 1997, 9, 115-120.

[47] G. Bagnasco, J. Catal., 1996, 159, 249-252.

[48] F. Lonyi, J. Valyon, Microporous Mesoporous Mater., 2001, 47, 293-301.

[49] H. L. Wang, W. Y. Xin, Catal. Lett., 2001, 76, 225-229.

[50] L. Rodriguez-Gonzalez, F. Hermes, M. Bertmer, E. Rodriguez-Castellon, A. Jimenez-Lopez, U. Simon, Appl. Catal. A, 2007, 328, 174-182.

[51] F. Benaliouche, Y. Boucheffa, P. Ayrault, S. Mignard, P. Magnoux, Microporous Mesoporous Mater., 2008, 111, 80-88.

[52] X. Wang, R. Li, C. Yu, Y. Liu, L. Zhang, C. Xu, H. Zhou, Fuel, 2019, 239, 794-803.

[53] S. Hayashi, N. Kojima, Microporous Mesoporous Mater., 2011, 141, 49-55.

[54] D. H. Zhou, N. He, Y. Q. Wang, G. Yang, X. C. Liu, X. H. Bao, J. Mol. Struct.-Theochem, 2005, 756, 39-46.

[55] J. Datka, B. Gil, A. Kubacka, Zeolites, 1995, 15, 501-506.

[56] M. Maache, A. Janin, J. C. Lavalley, E. Benazzi, Zeolites, 1995, 15, 507-516.

[57] J. Pastvova, R. Pilar, J. Moravkova, D. Kaucky, J. Rathousky, S. Shlenak, P. Sazama, Appl. Catal. A, 2018, 562, 159-172.

[58] N. S. Nesterenko, F. Thibault-Starzyk, V. Montouillout, V. V. Yuschenko, C. Fernandez, Microporous Mesoporous Mater., 2004, 71, 157-166.

[59] V. L. Zholobenko, M. A. Makarova, J. Dwyer, J. Phys. Chem., 1993, 97, 5962-5964.

[60] F. Wakabayashi, J. Kondo, A. Wada, K. Domen, C. Hirose, J. Phys. Chem., 1993, 97, 10761-10768.

[61] V. D. Dominguez-Soria, P. Calaminici, A. Goursot, J. Chem. Phys., 2007, 127, 154710.

[62] R. Bulanek, E. Koudelkova, M. Trachta, O. Bludsky, M. Rubes, Microporous Mesoporous Mater., 2020, 296,110007.

[63] Z. Chen, Y. Ni, Y. Zhi, F. Wen, Z. Zhou, Y. Wei, W. Zhu, Z. Liu, Angew. Chem. Int. Ed., 2018, 57, 12549-12553.

[64] M. Gao, H. Li, M. Yang, S. Gao, P. Wu, P. Tian, S. Xu, M. Ye, Z. Liu, Commun. Chem., 2019, 2, 1-10.

\section{无机体系合成纳米丝光沸石组装体及其优异的二甲醚孷基化催化性能

$$
\begin{aligned}
& \text { 曹凯鹏 }{ }^{\mathrm{a}, \mathrm{b}} \text {, 樊 栋 }{ }^{\mathrm{a}} \text {, 曾 姝, 娤本汉 }{ }^{\mathrm{a}, \mathrm{b}} \text {, 陈 南a, 高铭斌, }
\end{aligned}
$$

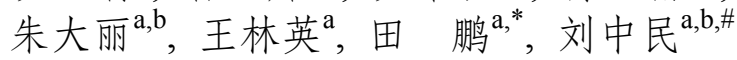 \\ a中国科学院大连化学物理研究所, 洁净能源国家实验室(筹), 甲醇制烯烃国家工程实验室, 辽宁大连116023 \\ b 中国科学院大学, 北京100049}

摘要: 乙醇是一种重要的有机化工原料和燃料/燃料添加剂. 二甲醚(DME)羰基化制乙酸甲酯(MAc)并进一步加氢制备乙 醇提供了一条乙醇生产新途径. 作为该路线的核心过程, DME羰基化制备MAc反应具有原子经济性高和反应条件温和等 特点, 近年来备受关注. 在DME羰基化制备MAc的多相催化剂中, 丝光沸石(MOR)是迄今为止最为高效的催化剂之一, 表 现出优异的羰基化反应活性和高MAc选择性. 但传统的无机体系合成方法只能得到Si/Al比(SAR)介于 5 7的MOR沸石, 且 晶体尺寸通常较大.

本文设计了低碱度凝胶体系和晶种法相结合的合成策略, 在无有机模板条件下绿色高效合成了SAR最高为9.4的MOR 沸石纳米组装体. 选取三个具有不同SAR(I-5.3, I-7.4和I-9.4)的样品进一步表征并与其催化性能相关联. 实验发现, 催化剂 的酸强度随着SAR的提高而明显增强, 但是三个样品的总酸量以及Brønsted酸在主孔道和侧口袋的分布比例接近. 利用傅 里叶变换红外和钠核磁技术分别对H-MOR及其Na-MOR母体样品中的酸着基和 $\mathrm{Na}^{+}$的空间分布进行分析, 发现质子在主孔 道与侧口袋的分布比例与 $\mathrm{Na}^{+}$的分布并不一致, 表明质子和 $\mathrm{Na}^{+}$可以落位于同一 $\mathrm{T}$ 位的不同氧位. 通过对催化剂扩散性质以 
及酸性位的可接触性的表征, 发现低硅样品I-5.3 和I-7.4尽管晶粒尺寸较小, 但由于孔道中骨架外铝的含量较高, 严重阻碍 内扩散, 并且导致吡啶对 12 元环主孔道中酸中心的可接触性降低. 相对于低硅样品, 高硅样品I-9.4由于其相对较低的骨架 铝密度和较低的脱铝程度, 表现出最优的传质性能以及吡啶对 12 元环主孔道中酸中心的可接触性, 催化剂主通道中的所有 酸性位都能被吡啶所覆盖. 相应地, 样品I-9.4(吡啶修饰催化剂)在DME羰基化反应中表现出较高的催化活性与MAc选择性 (接近 $100 \%$ ), MAc产率高达 $6.8 \mathrm{mmol} / \mathrm{g} / \mathrm{h}$. 综上, 本文发展的无有机模板策略合成MOR沸石纳米组装体具有良好应用前景.

关键词: 丝光沸石; 无有机模板合成; 二甲醚羰基化; 酸性质; 扩散

收稿日期: 2020-11-19. 接受日期: 2021-02-02. 上网时间: 2021-05-05.

*通讯联系人. 电子信箱: tianpeng@dicp.ac.cn

\#通讯联系人. 电子信箱: liuzm@dicp.ac.cn

基金来源：国家自然科学基金(21676262, 21991090, 21991091); 中国科学院前沿科学重点研究项目(QYZDB-SSW-JSC040); 中法 分子篮联合实验室(LIA)资助.

本文的电子版全文由Elsevier出版社在ScienceDirect上出版(http://www.sciencedirect.com/journal/chinese-journal-of-catalysis). 